\title{
Protein Hook Homolog 3
}

National Cancer Institute

\section{Source}

National Cancer Institute. Protein Hook Homolog 3. NCI Thesaurus. Code C97495.

Protein Hook homolog 3 (718 aa, $\sim 83 \mathrm{kDa}$ ) is encoded by the human HOOK3 gene. This protein plays a role in the mediation of endocytosis. 